\title{
Targeting Fatty Acid Metabolism in Head and Neck Cancer
}

\author{
Ji-Hoon Kim ${ }^{1,2} \mathbb{D}$, Minhee $\mathrm{Ku}^{2,3} \mathbb{D}$, Jaemoon Yang ${ }^{2,3} \mathbb{D}$, and Hyung Kwon Byeon ${ }^{2,4} \mathbb{D}$ \\ ${ }^{1}$ Department of Otorhinolaryngology, National Health Insurance Service Ilsan Hospital, Goyang; and \\ ${ }^{2}$ Systems Molecular Radiology at Yonsei, Seoul; and \\ ${ }^{3}$ Department of Radiology, Yonsei University College of Medicine, Seoul; and \\ ${ }^{4}$ Department of Otorhinolaryngology, Soonchunhyang University College of Medicine, Seoul, Korea
}

\section{두경부암의 지방산 대사 표적화}

김지훈 ${ }^{1,2}$ · 구민희 ${ }^{2,3}$ · 양재문 ${ }^{2,3}$ · 변형권 ${ }^{2,4}$

국민건강보험 일산병원 이비인후과, ${ }^{1}$ Systems Molecular Radiology at Yonsei, ${ }^{2}$ 연세대학교 의과대학 영상의학교실, ${ }^{3}$ 순천향대학교 의과대학 이비인후과학교실 ${ }^{4}$

Received February 1, 2021

Revised February 16, 2021

Accepted February 16, 2021 Address for correspondence Hyung Kwon Byeon, MD, PhD Department of Otorhinolaryngology, Soonchunhyang University College of Medicine, Soonchunhyang University Seoul Hospital, 59 Daesagwan-ro, Yongsan-gu, Seoul 04401, Korea

Tel +82-2-709-9360

Fax $+82-2-795-3687$

E-mail ewellcastle@gmail.com
Reprogramming of cellular metabolism is an important, emerging, and universal hallmark of cancer which has received considerable attention during the recent era of cancer research. Cancer cells show characteristic alterations in glucose metabolism in order to fulfill the needs of biosynthesis for tumor proliferation and growth. However, under certain circumstances such as invasion and metastasis, cancer cells are prone to metabolic stress and will require different strategies to meet the high energetic demand from cancer progression. From various metabolic rewiring mechanisms, cancer cells adopt other metabolic pathways with alternative nutrient sources. Therefore, targeting cancer metabolism holds promising but great challenge caused by the metabolic plasticity of cancer cells. This review will discuss characteristic cancer metabolism in detail with special focus on lipid metabolism which is gathering increasingly keen interest, in order to find novel therapeutic approaches to head and neck cancer. By understanding and exploiting the synthesis, oxidation, and storage of fatty acids, we could investigate potential strategies to block cancer proliferation and progression.

Korean J Otorhinolaryngol-Head Neck Surg 2021;64(6):381-90

Key Words Energy metabolism · Head and neck neoplasms · Lipid metabolism · Neoplasm invasiveness $\cdot$ Neoplasm metastasis.

\section{서 론}

발암 과정에 있어 정상 세포가 여러 가지 생물학적인 능력 들을 갖게 되고, 이러한 암세포의 특성들(hallmarks of cancer)은 암의 종류를 막론하고 공통적으로 보이는 현상으로 간주된다. ${ }^{1)}$ 특히, 세포 에너지 활용의 변화 혹은 에너지대사 의 재편성은 최근에 추가된 암의 중요 특성으로서, 암이 그

This is an Open Access article distributed under the terms of the Creative Commons Attribution Non-Commercial License (https://creativecommons.org/licenses/by-nc/4.0) which permits unrestricted non-commercial use, distribution, and reproduction in any medium, provided the original work is properly cited.
종류와 원인이 다양하게 존재함에도 불구하고, 이러한 성향 은 모든 암에서 공유된다. ${ }^{2)}$ 암세포 대사의 특징적인 변화로 대표적으로 거론되는 것이 와버그 효과(Warburg effect)이다. 이것은 암세포가 산소가 충분히 존재하는 조건임에도 불구 하고 에너지 대사적으로 효율이 높은 산화적 인산화(oxidative phosphorylation, OXPHOS) 과정보다 해당 과정(glycolysis)을 선호하는 현상을 일컫는 것으로서 호기성 해당 작용 (aerobic glycolysis)으로도 불린다. ${ }^{3)} \mathrm{OXPHOS}$ 과정을 통해 많은 양의 adenosine triphosphate(ATP)(포도당 한 분자당 36 개의 ATP)를 생산하는 대신 상대적으로 에너지 효율이 떨 
어지는 해당 과정(포도당 한 분자당 2개의 ATP)을 채택함으 로써 암세포는 보다 빠르게 $\mathrm{ATP}$ 를 생산하고, 활성 산소종 (reactive oxygen species, ROS)의 발생을 줄이고, 저산소의 종양미세환경(tumor microenvironment)에서 당대사의 안 정성을 갖추고, 중요하게는 당의 중간대사체가 여러 생합성 경로로 유입되는 것을 늘려, 궁극적으로 암세포 성장에 필요 한 뉴클레오티드(nucleotide), 아미노산, 지방 등의 바이오매 스(biomass) 합성을 통한 동화작용(anabolism)에 기여하게 되는 생물학적인 장점을 가지게 된다.

약 100 여 년 전 Warburg 등 ${ }^{4}$ 에 의해 본 이론이 처음 제기 될 당시에는, 암세포 내에서는 미토콘드리아의 기능 부전으로 인해 OXPHOS 과정이 손상되거나 억제되고 있다고 생각을 하였다. 그러나 이후에 암세포 내에서도 정상 세포와 마찬가 지로 OXPHOS 과정이 일어날 수 있다고 알게 되었으며, ${ }^{5-8)}$ 암세포가 놓인 다양한 환경에 따라 해당 작용과 OXPHOS 작용 간에 대사 전환(metabolic switch)을 통해 능동적으로 대처할 수 있음을 알게 되었다. 암세포 내에서는 당 흡수 증 가를 통해 당대사가 활성화되어 있지만, 당 이외의 다른 영양 분 흡수를 통해 미토콘드리아 내 tricarboxylic acid(TCA) 회 로가 활성화되기도 한다.

과거에는 암생물학에 있어 암대사(cancer metabolism)가 주류 학문으로서 큰 관심을 받지 못하다가, 최근에 들어서 암대사가 종양신호전달(oncogenic signal transduction)이나 종양면역(tumor immunity)과 마찬가지로 암생물학의 필수 요소로 그 관심이 증가하고 있다. 특히나 암대사 중에서도 지 방산 대사와 관련하여 그 역할에 대해 재조명되고 있어, 이 분 야에 대한 보다 깊은 이해를 통해 두경부암의 치료에 대한 새 로운 접근을 해 볼 수 있을 것이다. 본 종설에서는 특히 지방 산의 합성, 산화, 그리고 저장에 초점을 맞추어 암세포 내에서 보이는 대사에 대해 살펴보고, 이를 통해 암의 증식과 진행을 억제할 수 있는 전략들을 모색해보고자 한다.

\section{본 론}

\section{암세포의 특이적 당대사(Characteristic glucose metabolism in cancer cells)}

암세포는 증식과 성장을 위해서 당대사(glucose metabolism)를 활용하게 되는데, 이는 여러 암 돌연변이에 따른 신 호 전달의 강화를 통해 일어나게 된다. 이러한 현상을 임상적 으로 적용한 예가 암세포가 포도당의 유사체인 $18^{\mathrm{F}}-\mathrm{fluoro}-$ deoxyglucose를 흡수함으로써, 암의 진단 및 치료 전후 반응 성 평가 등에 활용할 수 있는 검사인 양전자방출단층촬영술 (positron emission tomography, PET)이다. 여하튼 암세포의
여러 구성 요소(building block)의 합성이 필요한 상황에서, 세포 내로 흡수된 포도당이 오로지 미토콘드리아 내의 OXPHOS 과정을 통해 분해되어 많은 양의 ATP를 생산하는 것 만으로는 도움이 되지 않고, 포도당의 고분자 전구물질로의 전환이 필수적인데, 가령 지방산 합성을 위한 acetyl-CoA, 비 필수 아미노산 합성을 위한 해당 중간체(glycolytic intermediates), 그리고 뉴클레오티드의 합성을 위한 라이보오스(ribose)의 생성이 그것이다(Fig. 1).

각종 성장 인자 및 $\mathrm{PI} 3 \mathrm{~K} / \mathrm{Akt}$ 등의 종양 신호 전달에 의해 포도당 수송체가 활성화되어 포도당 세포 내로의 흡수가 증 가되고, 헥소키나아제(hexokinase), 포스포프룩토키나아제 (phosphofructokinase, $\mathrm{PFK}$ )를 비롯한 해당 작용의 주요 효 소들의 기능 조절을 통해 해당 작용은 강화된다. ${ }^{9,10)}$ 더 나아 가, 타이로신인산화효소(tyrosine kinase) 성질을 가지는 많은 수의 암유전자들은 피루브산염 키나아제(pyruvate kinase) 의 활성을 특이적으로 억제하여 이러한 일련의 현상들이 당 중간대사체인 포도당-6-인산(glucose-6-phosphate, G6P) 이 펜토오스 인산 경로(pentose phosphate shunt, PPP)로의 유입을 늘려 뉴클레오티드 합성을 용이하게 한다(Fig. 1). 이 과정에서 포도당-6-인산탈수소효소(G6P dehydrogenase, G6PD)와 6-포스포글루콘산탈수소효소(6-phosphogluconate dehydrogenase, 6PGD) 두 효소에 의해 nicotinamide adenine dinucleotide phosphate(NADPH) 또한 생성되는데, 이를 통해서 합성에 필요한 전자(electrons)를 전달받게 되고, 또한 산화 환원 조절(redox control)을 할 수 있게 된다. 뿐만 아니라 해당 중간체 중의 하나인 3-인글리세르산(3-phosphoglycerate)의 생성 역시 증가되어 세린 생합성 경로(serine biosynthesis pathway)를 통해 비필수 아미노산 생성을 늘리 게 된다. 암억제 인자로 잘 알려진 $\mathrm{p} 53$ 은 $\mathrm{PFK}$ 와 인산글리세 르산변위효소-1(phosphoglycerate mutase-1)을 억제하여 해당 중간체가 각각 $\mathrm{PPP}$ 와 세린 생합성 경로로의 유입을 증 가시킨다(Fig. 1). 또한 지방산 합성을 위해 필요한 탄소는 포 도당의 acetyl-CoA로의 전환을 통해서 얻을 수 있게 된다.

해당 작용을 통해 생성된 피루브산염은 젖산탈수소효소 (lactate dehydrogenase, LDH)를 통해 젖산(lactate)으로 변 환되고, 이로써 과다한 탄소는 배출되고 또한 $\mathrm{NADPH}$ 의 생 성을 돕는다. 젖산은 모노카복실레이트 수송체(monocarboxylate transporter, MCT)의 하나인 MCT4를 통해 암세포 밖으로 배출되지만, 일부 암세포에 따라서는 거꾸로 MCT1을 통해 다시 암세포 내로 흡수하여 미토콘드리아 내 OXPHOS 과정에 이용된다는 연구도 보고된 바 있다. ${ }^{11)}$ 암세포에서는 $\mathrm{Myc}$ 를 통해 $\mathrm{LDH}$ 와 $\mathrm{MCT}$ 의 발현이 증가되어 있다. ${ }^{12)} \mathrm{Myc}$ 는 또한 글루타민(glutamine)의 세포 내 흡수와 분해(glutami- 


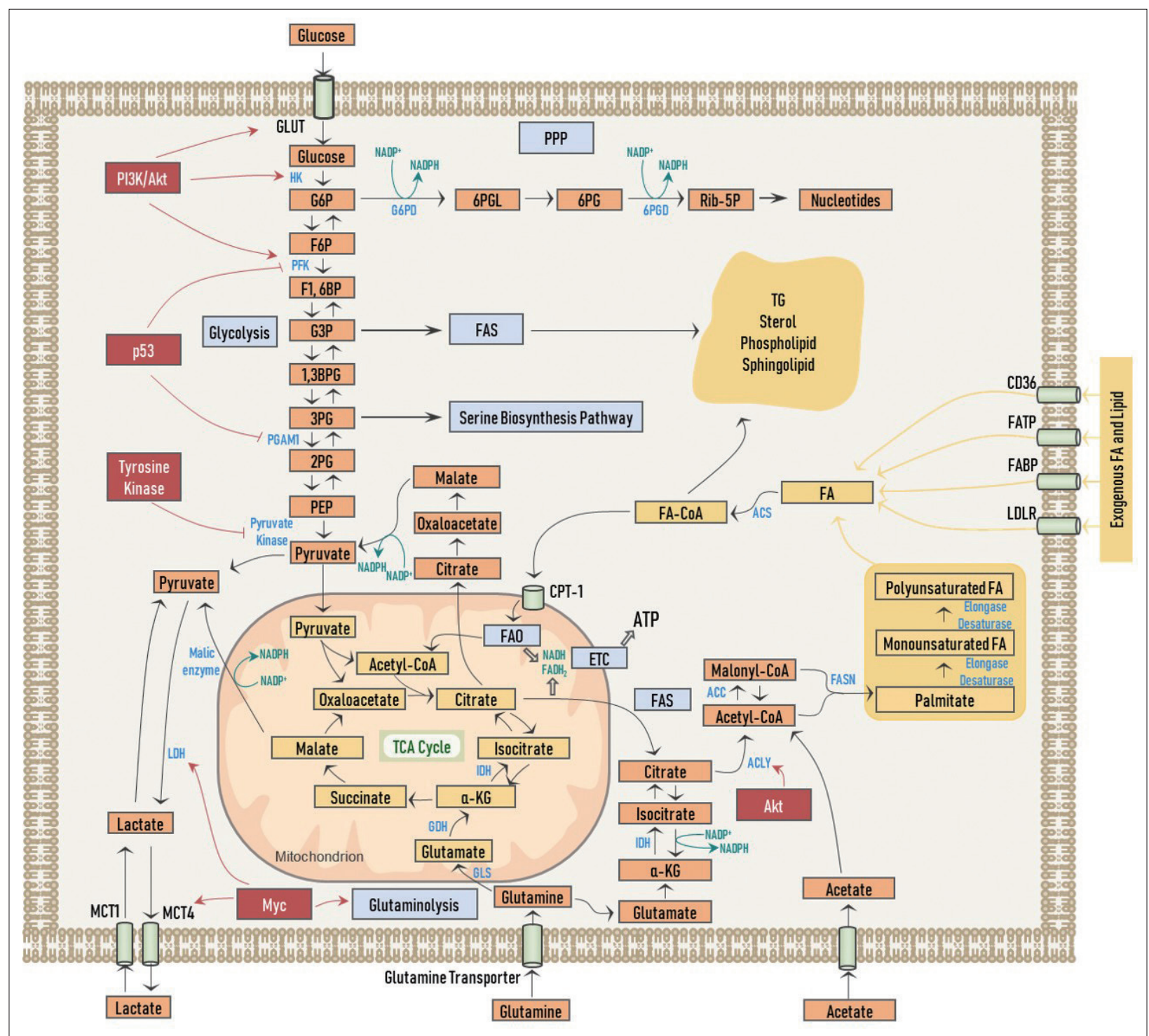

Fig. 1. Overview of cancer cell metabolism. Regulation of metabolism by oncogenic signaling pathways are also shown. See text for detailed description of depicted pathways. GLUT: glucose transporter, MCT1: monocarboxylate transporter1, MCT4: monocarboxylate transporter4, FATP: fatty acid transport protein, FABP: fatty acid binding protein, LDLR: low-density lipoprotein receptor, CPT-1: carnitine palmitoyl transferase-1, G6P: glucose-6-phosphate, F6P: fructose-6-phosphate, F1,6BP: fructose-1,6-biphosphate, G3P: glyceraldehyde-3-phosphate, 1,3BPG: 1,3-biphosphoglycerate, 3PG: 3-phosphoglycerate, 2PG: 2-phosphoglycerate, PEP: phosphoenolpyruvate, 6PGL: 6-phosphogluconolactone, 6PG: 6-phosphogluconate, Rib-5P: ribose-5-phosphate, a-KG: a-ketoglutarate, HK: hexokinase, PFK: phosphofructokinase, PGAM1: phosphoglycerate mutase-1, LDH: lactate dehydrogenase, G6PD: glucose-6-phosphate dehydrogenase, 6PGD: 6-phosphogluconate dehydrogenase, IDH: isocitrate dehydrogenase, GDH: glutamate dehydrogenase, GLS: glutaminase, ACLY: ATP-citrate lyase, ACC: acetyl-CoA carboxylase, FASN: fatty acid synthase, ACS: acyl-CoA synthetase, PPP: pentose phosphate shunt, FAS: fatty acid synthesis, FAO: fatty acid oxidation, ETC: electron transport chain, TCA: tricarboxylic acid, TG: triacylglycerol, FA: fatty acid, NADP: nicotinamide adenine dinucleotide phosphate (oxidized form), NADPH: nicotinamide adenine dinucleotide phosphate (reduced form), ATP: adenosine triphosphate, FA-CoA: fatty acid-CoA.

nolysis)를 활성화시켜 글루타민산(glutamate)이 말린산염 (malate)과 피루브산염(pyruvate)을 거치면서 NADPH의 생 성을 촉진시킨다(Fig. 1).

\section{대사의 재편성(Reprogramming of metabolism)}

성장하는 암세포에서 해당 과정을 증식성 대사(proliferative metabolism)로 활용하는 것에 반해, 전이성 침습성 암세
포에서는 다른 방향으로 대사가 재편성된다(Fig. 2). 이동 중 인 전이암세포에서는 포도당의 흡수가 감소되고, 이로 인해 $\mathrm{PPP}$ 로부터의 $\mathrm{NADPH}$ 생산이 감소되어 세포 내 산화 환원 능력이 떨어져 ROS 발생이 증가하게 된다. 게다가 ATP 생산 또한 감소하게 되어 이러한 일련의 에너지, 산화적 스트레스 (energetic and oxidative stress)로 인해 암세포는 세포사의 위기에 놓이게 된다. 그러나 그에 따라 암세포 내에서는 ATP 


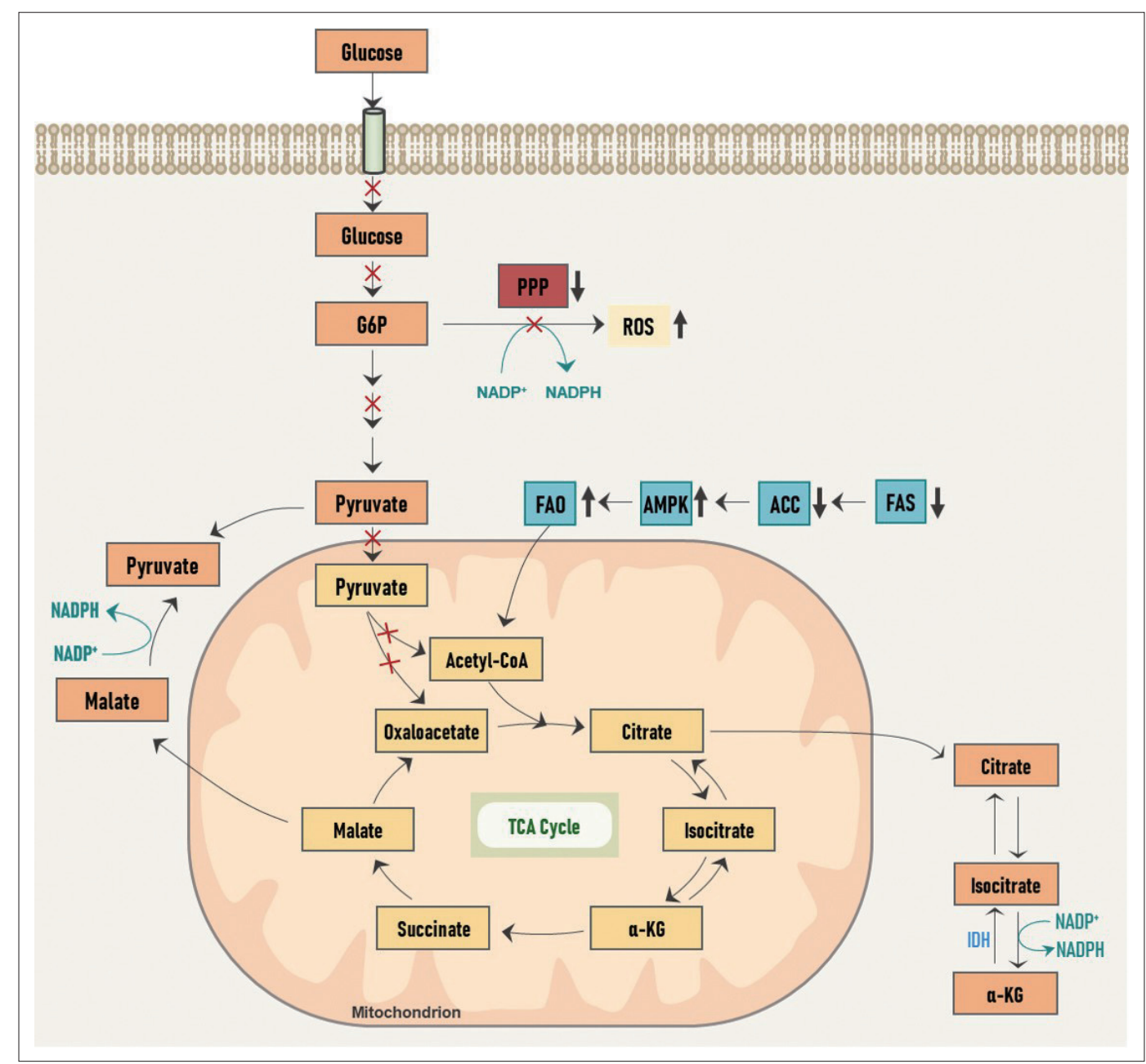

Fig. 2. Reprogramming of metabolism in metastatic, invasive cancer cells. Cancer cells during migration and invasion undergo alterations in metabolism in order to survive the energetic and oxidative stress. Lipid metabolism has a central role during invasive metabolism of cancer. G6P: glucose-6-phosphate, $\alpha$-KG: $\alpha$-ketoglutarate, PPP: pentose phosphate shunt, FAO: fatty acid oxidation, AMPK: AMP-activated protein kinase, AMP: adenosine monophosphate, ACC: acetyl-CoA carboxylase, FAS: fatty acid synthesis, ROS: reactive oxygen species, TCA: tricarboxylic acid, IDH: isocitrate dehydrogenase, NADP: nicotinamide adenine dinucleotide phosphate (oxidized form), NADPH: nicotinamide adenine dinucleotide phosphate (reduced form).

의 감지자(sensor)인 adenosine monophosphate(AMP)-활성 단백질 인산화효소(AMP-activated protein kinase, AMPK) 가 활성화되고 acetyl-CoA 카복실화효소(acetyl-CoA carboxylase, ACC)가 억제되어 지방산 합성(fatty acid synthesis, FAS)은 억제되고 지방산 산화(fatty acid oxidation, FAO) 는 활성화된다. FAS가 감소함으로써 $\mathrm{NADPH}$ 소모량은 줄어 들고, $\mathrm{FAO}$ 가 증가함으로써 말린산염에서 피루브산염으로의 전환과 아이소구연산염(isocitrate)에서 알파-케토글루타르 산 $(\alpha-k e t o g l u t a r a t e, ~ \alpha-K G)$ 로의 전환이 각각 활성화되고, 이 과정에서 $\mathrm{NADPH}$ 생산이 증가하여 부족한 양을 보충할 수 있게 된다. 또한 $\mathrm{FAO}$ 를 통해 미토콘드리아 내 OXPHOS를 통해 많은 양의 ATP를 생산하게 된다. 이처럼 침습성 대사 (invasive metabolism)에서는 지방산의 대사가 중요한 역할 을 한다.
암세포에서의 지방대사(Lipid metabolism in cancer cells)

지질은 다양한 군으로 이루어진 소수성의 생분자물질로서 인지질(phospholipids), 스핑고지질(sphingolipids), 트리아실 글리세롤(triacylglycerols, TG), 스테롤(sterols) 등을 포함하 며 지방산이 기본 합성단위가 된다. 지방산은 다양한 탄소의 수를 가지는 탄화수소 사슬이 그 말단에 카복시기(carboxyl group)가 붙어 있는 구조로 이루어져 있으며 다양한 포화도 를 보인다. 세포 내에서 지방산은 세포막의 구성 성분이 되기 도 하고, 에너지 대사 및 저장, 그리고 신호전달물질로써도 활 용이 된다. 암세포에서의 지방산 대사 중 대부분 연구의 초점 은 주로 FAS에 맞추어졌으나, 최근 들어 암에서의 $\mathrm{FAO}$ 의 역 할에 대해서도 관심이 증가하고 있다. 


\section{지방산 합성(FAS)}

암세포가 지방산을 얻는 방법은 세포 외부로부터 흡수를 하거나, 세포 내에서 직접 합성을 하는 2 가지 경로로써 가능 하다(Fig. 1). 정상 세포에서는 주로 지방산의 외인성 흡수를 통해 지방 필요량을 보충하는 데 반해서 암세포에서는 상대 적으로 지방산의 신생합성(de novo FAS)이 활성화되어 있는 것으로 알려져 있다. 그러나 최근에는 암세포에서도 주변 환 경의 지방산을 필요에 따라 활발히 흡수하고, 암의 진행에 있 어 이러한 외인성 지방산 흡수와 지방산의 신생합성 모두가 중요하다는 연구 결과들이 늘고 있다. ${ }^{13,14)}$ 특히, 암세포는 필요 에 따라 주위 종양미세환경의 지방세포(adipocyte)로부터 유 리된 지방산을 흡수하여 지방대사에 활용할 수 있다..$^{15-18)}$ 지 방산을 세포 내로 흡수하는 역할을 담당하는 대표적인 수송 체로는 CD36, 지방산수송단백질(fatty acid transport proteins, FATPs), 지방산결합단백질(fatty acid binding proteins, FABPs), low-density lipoprotein receptor 등이 있다.

FAS의 첫 단계는 구연산염(citrate)으로서, 이는 주로 앞서 살펴본 해당 과정의 산물인 피루브산염이 TCA 회로를 경유 하여 생성된다. 그러나 저산소 환경이나 미토콘드리아의 기능 이 억제되어 있는 경우에 TCA 회로가 돌아갈 수 없게 되어, 암세포는 대체 영양소로서 글루타민을 세포 내로 흡수하여 $\alpha-\mathrm{KG}$ 를 생성하고, 아이소구연산염 탈수소효소(isocitrate dehydrogenase, IDH)에 의한 환원성 카복시화 반응(reductive carboxylation)를 통해 구연산염을 생성하게 된다. ${ }^{19)}$ 구연 산염은 이어서 ATP-구연산염 분해효소(ATP-citrate lyase, $\mathrm{ACLY})$ 에 의해 acetyl-CoA로 전환되는데, 암세포에서는 Akt 를 통해 ACLY의 활성화를 촉진시켜 acetyl-CoA의 합성을 증가시킨다. ${ }^{20)}$ 암세포는 때로는 $\mathrm{MCT}$ 를 통해 외부에서 아세 트산염(acetate)을 흡수하여 acetyl-CoA를 직접 생성하기도 한다. 해당 과정이 상대적으로 저조하고 지방산 대사가 활성 화되어 있는 암에서는 이러한 현상을 이용하여 영상학적인 진단 검사가 가능한데, C11-acetate PET 검사가 그 예이다. ${ }^{21)}$ Acetyl-CoA는 이어서 속도제한효소(rate-limiting enzyme) 인 $\mathrm{ACC}$ 에 의해 malonyl-CoA로 전환된다. Malonyl-CoA 로부터 지방산 합성효소(fatty acid synthase, FASN)에 의해 비로소 포화지방산인 팔미테이트(palmitate)가 생성이 된다. 팔미테이트는 이후에 여러 신장효소(elongase)와 불포화효 소(desaturase)의 작용에 의해 다양한 탄소의 수와 포화도를 가지는 지방산들을 생성하게 된다. 이와 같이 생성된 지방산 들은 아실-CoA 합성효소(acyl-CoA synthetase)에 의해 fatty $\mathrm{acid}-\mathrm{CoA}$ 로 가공이 되어 세포막의 구성 성분으로 중요한 인 지질이나 스핑고지질로 전환되거나, $\mathrm{TG}$ 와 스테롤로 바뀌어 지방 방울(lipid droplet, LD)의 형태로 저장이 된다. 에너지
저장소인 $\mathrm{LD}$ 는 추후에 암세포가 필요시 $\mathrm{FAO}$ 의 연료로서 공 급하게 된다.

$\mathrm{ACLY}, \mathrm{ACC}, \mathrm{FASN}$ 등 FAS에 관여하는 주요 효소들은 스테롤 조절 요소 결합 단백질-1(sterol regulatory element binding protein-1, SREBP-1)이라는 전사조절인자에 의해 발현되고, $\mathrm{SREBP}$ 는 $\mathrm{PI} 3 \mathrm{~K} / \mathrm{Akt} / \mathrm{mTORC}$ 종양 신호에 의해 활성화된다.

세포 내에서는 포화지방산 대비 불포화지방산의 비율이 일 정하게 유지되는 것이 중요한데, 포화지방산이 과도하게 쌓이 게 되면 이로 인해 미토콘드리아의 기능 이상, ROS 증가, 소 포체(endoplasmic reticulum, ER) 스트레스 등이 발생하여 세포에 치명적인 손상을 가져다줄 수 있게 된다. 따라서 지방 산의 탈포화(desaturation)를 유도하는 스테아로일- $\mathrm{CoA}$ 불 포화효소(stearoyl-CoA desaturase, $\mathrm{SCD}$ )의 역할이 중요한 데, 이 효소는 특이적으로 산소가 충분한 환경에서 작용이 원 활하게 이루어진다. 암세포에서는 $\mathrm{SCD}$ 의 발현이 증가되어 있 는 것으로 알려져 있으며,22,23) 저산소 환경에 놓인 암세포에 서는 $\mathrm{SCD}$ 의 활성이 억제되어 불포화지방산의 생성이 감소하 기에, 이러한 상황에 대비하여 암세포는 LD 내의 불포화지방 산의 유리를 증가시키거나 ${ }^{24)}$ 저산소증유발인자- $1 \alpha$ (hypoxiainducible factor-1 $\alpha$ ) 발현 증가를 통해 외부 환경으로부터 불포화지방산의 흡수를 늘려서 지방독성(lipotoxicity)으로부 터 세포를 보호하게 된다. ${ }^{25)}$

포화지방산과 불포화지방산의 세포 조성은 세포막의 유동 성(fluidity)에도 깊은 영향을 미친다. 즉, 포화지방산의 비율 이 높을수록 세포막은 견고해지고 유동성은 감소하게 되고, 이러한 경우 암세포는 약물 흡수 감소로 인해 항암제로부터 저항성을 가질 수 있게 된다. ${ }^{26)}$ 반면에, 불포화지방산의 비율 이 높은 암세포에서는 세포막의 구성이 느슨해져 유동성은 증가하여 이로 인해 암세포의 이동과 전이를 용이하게 한다. ${ }^{27)}$ 이처럼, 지방산의 조성에 따른 세포막의 유동성을 조절하여 암세포는 각 필요 상황에 맞도록 이점을 취할 수 있게 된다.

\section{지방산 산화(FAO)}

앞서 언급한 바와 같이, 전이성 암세포에서는 포도당의 흡 수가 줄어들고 암세포의 이동과 침습의 과정에서 많은 양의 $\mathrm{ATP}$ 를 필요로 하게 되는데, 이러한 상황에서 가장 효율적으 로 에너지를 생산할 수 있는 방법이 FAO이다. 탄수화물과 비 교해서 지방산은 2 배나 많은 양의 $\mathrm{ATP}$ 를 제공할 수 있다. 두 경부암세포 중에서도 전이를 유발하는 일부 세포들에서 지방 산의 수용체인 CD36의 발현과 함께 지방대사 관련 유전자 의 발현이 높은 것을 확인한 연구가 있으며,13) 이 특정 암세포 군에 팔미테이트 혹은 고지방식이(high fat diet) 처리 시에 원 
발 부위 암의 변화는 미미하고, 특이하게 암세포의 전이만을 촉진시켰고, 반대로 $\mathrm{CD} 36$ 을 억제 시에 원발 부위의 암에 대 한 영향없이 암의 전이만 선택적으로 억제할 수 있음을 확인 한 바 있다. 뿐만 아니라, 원발 부위의 암과 비교하여 림프절로 전이가 이루어진 암세포를 분석한 결과, $\mathrm{FAO}$ 와 관련된 유전 자의 발현이 증가되어 있으며, 이는 특이하게 활성화된 yes연관 단백질(yes-associated protein, YAP)이라는 전사인자 에 의해 유도됨을 확인한 연구 결과도 있다. ${ }^{28)}$ 이 연구에서도 $\mathrm{FAO}$ 를 억제하는 약물을 투여하거나 YAP 발현을 억제했을 때 림프절 전이를 선택적으로 억제할 수 있었다. 이를 토대로 볼 때 $\mathrm{FAO}$ 를 억제하는 것이 암의 침습과 전이를 억제할 수 있는 효과적인 전략임을 짐작해 볼 수 있을 것이다.

지방산은 이처럼 $\mathrm{CD} 36$ 을 통해 외부에서 세포 내로 흡수가 되거나 $\mathrm{LD}$ 내에 저장되어 있던 $\mathrm{TG}$ 로부터 유리되어, 카르니틴 팔미토일 전이효소(carnitine palmitoyl transferase-1)에 의해 미토콘드리아 내로 이동하여 $\mathrm{FAO}$ 가 이루어진다. $\mathrm{FAO}$ 혹은 베타 산화과정( $\beta$-oxidation)의 결과로 acetyl-CoA, nicotinamide adenine dinucleotide(NADH), flavin adenine dinucleotide $\left(\mathrm{FADH}_{2}\right)$ 가 생성되고, acetyl-CoA는 $\mathrm{TCA}$ 회로 로 유입되어 $\mathrm{NADH}$ 가 생성되고, $\mathrm{NADH}$ 와 $\mathrm{FADH}_{2}$ 는 전자전 달계(electron transport chain, ETC)로 유입되어 ATP가 발 생하게 된다(Fig. 1). 미토콘드리아 내 acetyl-CoA가 TCA 회 로를 통해 $\mathrm{NADH}$ 를 생성하지만, 함께 구연산염 또한 생성되 어 세포질로 유출되고, 이어서 다음의 두 가지 경로로 연결되 어 그 과정에서 $\mathrm{NADPH}$ 가 생성된다: 1) 각각 연속적으로 옥 살로아세트산염(oxaloacetate), 말린산염, 피루브산염으로 전 환되는 경로, 2) $\mathrm{IDH}$ 에 의해 아이소구연산염에서 $\alpha-\mathrm{KG}$ 로 변 환되는 경로. 이처럼 생성된 $\mathrm{NADPH}$ 는 전술한 바와 같이 전 이성 암세포에서 $\mathrm{ROS}$ 발생 증가로 인한 산화적 스트레스를 감소시키는 항산화제로서의 역할을 하지만, 한편으로는 동화 작용에 관여하는 여러 효소들에 대한 조효소로서 작용하여 증식성 암세포의 합성 과정에도 이용될 수 있다. 요약하자면, 암세포에서는 필요시 $\mathrm{FAO}$ 의 과정을 통해 $\mathrm{ATP}$ 와 $\mathrm{NADPH}$ 를 공급받을 수 있는 것이다. ${ }^{29}$ 또한, $\mathrm{FAO}$ 를 통해 생성된 acetyl$\mathrm{CoA}$ 는 구연산염으로의 변환 과정을 거쳐 세포질 내 acetyl$\mathrm{CoA}$ 로 다시 변환되어 $\mathrm{FAS}$ 로 이어질 수도 있다는 점을 미루 어 보아, $\mathrm{FAO}$ 와 FAS는 필요에 따라 상호 보완적인 관계로 세포에 유용하게 작용할 수 있다.

\section{지방 대사의 치료 표적(Therapeutic targets in lipid metabolism)}

지금까지 살펴봤듯이 암세포 내에서는 특이적인 지방 대사 를 통해 외부 환경에 따라 대사적 가소성(metabolic plastici-
Table 1. Drugs targeting cancer cell specific lipid metabolism

\begin{tabular}{|c|c|c|c|}
\hline Target & Drug & Comments & References \\
\hline \multirow[t]{8}{*}{ FASN } & Orlistat & FDA approved & $31,35)$ \\
\hline & Cerulenin & & $32,35)$ \\
\hline & C75 & & $32,35)$ \\
\hline & IPI-9119 & & 33) \\
\hline & EGCG & $\begin{array}{l}\text { Green tea leaf } \\
\text { extract }\end{array}$ & $34,35)$ \\
\hline & TVB-3166 & & 39) \\
\hline & TVB-2640 & & 40) \\
\hline & Triclosan & & 64) \\
\hline \multirow[t]{2}{*}{ ACLY } & LY294002 & PI3K inhibitor & 41) \\
\hline & SB-204990 & & 42) \\
\hline \multirow[t]{2}{*}{$\mathrm{ACC}$} & Soraphen A & & 43) \\
\hline & TOFA & $\begin{array}{l}\text { Also inhibits SCD } \\
\text { activity }\end{array}$ & $44,45,54)$ \\
\hline Glutaminase & BPTES & & 46) \\
\hline \multirow[t]{2}{*}{ SREBP-1 } & fatostatin & & $47,48)$ \\
\hline & betulin & & 49) \\
\hline \multirow[t]{4}{*}{ SCD } & Betulinic acid & & 55) \\
\hline & SSI-4 & & 56) \\
\hline & MF-438 & & 57) \\
\hline & BZ36 & & 65) \\
\hline \multirow[t]{3}{*}{ CPT-1 } & Etomoxir & & $28,59)$ \\
\hline & Perhexiline & & 60) \\
\hline & Oxfenicine & & 66) \\
\hline \multirow[t]{2}{*}{ 3-KAT } & trimetazidine & & 61) \\
\hline & ranolazine & FDA approved & 62) \\
\hline \multirow[t]{3}{*}{ ETC } & Metformin & Also activates & 63) \\
\hline & & AMPK & \\
\hline & Phenformin & & 67) \\
\hline
\end{tabular}

FASN: fatty acid synthase, ACLY: ATP-citrate lyase, ATP: adenosine triphosphate, ACC: acetyl-COA carboxylase, SREBP-1: sterol regulatory element binding protein-1, SCD: stearoyl-COA desaturase, CPT-1: carnitine palmitoyl transferase-1, 3-KAT: 3-ketoacylthiolase, ETC: electron transport chain, FDA: Food and Drug Administration, PI3K: phosphoinositide 3-kinase, AMPK: AMP-activated protein kinase, AMP: adenosine monophosphate

ty)을 보이고 있으며, 따라서 암의 이러한 생존 전략을 역이용 하여 암치료의 표적으로 모색해볼 수 있을 것이다(Table 1).

\section{지방산 합성의 표적화(Targeting FAS)}

외인성 지방산의 세포 내 흡수를 담당하는 막단백질을 치 료 표적으로 하는 전략을 통해 암세포의 지방산 공급을 막을 수 있다. 항CD36 항체를 통해 항암 효과가 있음을 확인하였 으며, ${ }^{13,14}$ FATP 및 FABP에 대한 억제 약물을 통해서도 암의 전이를 효과적으로 줄일 수 있음을 확인한 바 있다. ${ }^{15,30)}$

이와 대별하여 암세포 내의 지방산 신생 합성을 표적으로 하는 치료 전략에 대한 연구들도 활발히 진행 중이다. 정상 
세포에 비해 암세포 내에서 지방산의 신생 합성이 상대적으 로 활성화되어 있기에 매력적인 항암전략으로서 주목을 많이 받고 있다. 지방산 신생 합성 과정에서 작용하는 효소 중에서 FASN을 억제하는 여러 약물이 개발되어 많은 연구가 있었는 데, orlistat, cerulenin, C75, IPI-9119, EGCG가 그 예이다. ${ }^{31-35)}$ 그러나 동물 실험을 통해 이러한 약을 사용했을 때 급격한 체중 소실이나 신경줄기세포의 기능 이상으로 일부 심각한 부작용이 확인되어 임상 적용에는 아직 세심한 주의가 필요 한 상황이다. ${ }^{32,36)}$ 뿐만 아니라, FAS 억제를 통해 상대적으로 $\mathrm{FAO}$ 활성화를 통한 암 전이가 증가되었다는 결과도 있어, ${ }^{37,38)}$ 광범위한 암의 적용보다는 암의 각 진행 단계에 맞는 치료 전 략을 시사한다. 그러나 최근에는 FAS 억제를 하지만 간접적 인 FAO 활성화 효과를 보이지 않는 TVB-3166이나 TVB2640과 같은 차세대 FASN 억제제가 개발되어, 지방 조직 소 실 및 심각한 체중 감소 등의 부작용 없이 보다 특이적인 FAS 억제 효과를 보여 탁월한 항암효과의 가능성을 보인 결과도 있다. ${ }^{39,40)} \mathrm{FASN}$ 이 외에도 ACLY와 ACC를 표적으로 하는 치료 전략에 대해서도 많은 연구가 되어, 임상 적용의 잠재적 가능성을 엿볼 수 있다. ${ }^{41-44)}$ 특히나 epidermal growth factor receptor 억제제인 cetuximab에 대한 저항성을 보이는 두경 부암세포에서 cetuximab과 함께 ACC 억제제인 TOFA를 병 용처리하였을 때에 효과가 있었다는 보고도 있다. ${ }^{45}$ 뿐만 아 니라 암세포는 상황에 따라 대체영양소로서 글루타민을 흡 수하여 글루타민대사 과정을 통해 TCA 회로로 유입되거나 구연산염으로 전환되어 FAS로 이어지는데, 글루타민 분해 효소(glutaminase)를 억제하는 약물인 BPTES 처리를 통해 두경부암세포의 성장을 저해할 수 있었다는 결과도 보고된 바 있다. ${ }^{46)}$

$\mathrm{ACLY}, \mathrm{ACC}, \mathrm{FASN}, \mathrm{SCD}$ 등 $\mathrm{FA}$ 합성 과정에 관련된 효 소들의 발현은 전사조절인자인 $\mathrm{SREBP}-1$ 에 의해 조절된다. 그러나 SREBP-1는 전사인자이기에 이를 직접 억제하는 약 물 개발은 어렵고 SREBP-1과 관련된 단계에서 유용한 치료 전략을 생각해볼 수 있다. SREBP-1이 활성화되기 위해서는 SREBP-1이 SREBP-분열 활성화 단백질(SREBP-cleavage activating protein, $\mathrm{SCAP}$ )과 결합하여 ER에서 골지체(golgi apparatus)로 이동을 하게 된다. SREBP-1과 SCAP의 결합 을 방해하는 약물이 개발되어 항암효과가 있음을 확인한 바 있는데 fatostatin, betulin 등이 그 예이다. ${ }^{47-49)}$ 그 밖에도 SREBP-1의 상위 조절인자인 간 X 수용체(liver X receptor) 를 억제하는 전략에 대한 연구도 보고된 바 있다. ${ }^{50,51)}$

요컨대 암세포는 지방산 신생 합성뿐만 아니라 외인성 지 방산 흡수를 통해서도 세포가 필요한 지방산 공급을 받을 수 있기에, 이 두 과정을 모두 막는 것이 더 효과적인 치료 전략
일 수 있다. 한편, 전술한 바와 같이 지방산 합성을 통해 생성 된 팔미테이트는 여러 신장효소와 불포화효소의 작용을 통 해 다양한 단일불포화지방산(monounsaturated fatty acid)과 다불포화지방산(polyunsaturated fatty acid)을 생성하여 세 포가 필요한 다양한 용도로 활용되는데, 암세포의 신장효소 와 불포화효소를 각각 억제하여 암의 증식과 성장을 억제할 수 있다는 결과가 보고된 바 있다. ${ }^{52-54)}$ 특히 대표적인 불포화 효소인 SCD에 대한 억제제가 많이 개발되고 연구되었는데, betulinic acid, SSI-4, MF-438 등이 있다. ${ }^{55-57)}$ 그러나 일부 암 세포에서는 SCD 억제제를 처리하였을 때 외인성 지방산 흡수 나 다른 불포화효소의 작용을 통해 불포화지방산의 공급을 유지하여 $\mathrm{SCD}$ 억제제에 대한 저항성을 보인 경우도 있다. 25.58$)$

\section{지방산 산화의 표적화(Targeting $\mathrm{FAO}$ )}

$\mathrm{FAO}$ 의 가장 첫 단계이자 속도 조절 단계(rate-limiting step)인 CPT- 1 의 작용을 억제하는 약제가 개발되어 암의 성 장 및 진행을 제어할 수 있다는 결과들이 보고된 바 있는데, etomoxir와 perhexiline 등이 그 대표적인 예이다. ${ }^{28,59,60)}$ 그 밖에도 $\mathrm{FAO}$ 의 마지막 단계에서 작용하는 효소인 3-케토아 실티올분해효소(3-ketoacylthiolase)에 대한 억제제도 개발 된 바 있는데 trimetazidine, ranolazine 등이 있다. ${ }^{61,62)}$ 또한, $\mathrm{FAO}$ 자체를 억제하기보다는 그 이후에 ETC에서 ATP가 생 성되는 과정을 표적으로 하는 ETC 억제제들에 대한 항암효 과도 많이 보고되었는데, 익히 당뇨병 치료약제로도 잘 알려 진 metformin과 phenformin 등이 있다. Metformin은 특히 나 $\mathrm{AMPK}$ 를 활성화시키는 작용도 있어, 이를 통해 $\mathrm{ACC}$ 가 억제되고 이어서 $\mathrm{FAS}$ 가 차단되어 항종양 효과를 보인다는 결과도 있다. ${ }^{63)}$

\section{요약 및 결론}

암세포는 산소가 충분한 환경에서도 해당 과정과 OXPHOS 를 통한 피루브산염의 산화 과정을 분리함으로써, 탄수화물 이 최대치의 ATP를 생산하는 대신 암세포 성장에 필요한 동 화작용에 당대사를 특이적으로 이용한다. 이와 더불어 증식 성 암대사(proliferative cancer metabolism)는 활성화된 FAS 을 통해 에너지 저장, 세포막 합성, 신호전달 등을 위해 지방 산을 이용한다. 그러나 때로는 진행성 암에서는 암세포의 전 이와 이동을 위해 침습성 대사를 활용하게 되는데, 지방산의 대사가 중요한 역할을 한다. $\mathrm{FAO}$ 를 통해 대사적 스트레스에 놓인 암세포에 ATP와 $\mathrm{NADPH}$ 공급을 할 수 있게 된다. 이처 럼 암 성장의 각 단계, 혹은 암이 놓여진 환경에 맞추어 FAS 와 $\mathrm{FAO}$ 의 각 단계를 표적으로 한 치료를 고려해볼 수 있을 
것이고, 다양한 암종에 적용한 여러 결과가 보고되고 있다. 두경부암은 아직 상대적으로 적용 범위가 넓지 않으나, 이미 타암종에서 적용한 긍정적인 결과들을 토대로 지방산 대사의 새로운 치료 전략 가능성을 기대해 볼 수 있을 것이다.

\section{Acknowledgments}

This work was supported by the National Research Foundation of Korea (NRF) grants funded by the Korea government (MSIT) (No. NRF-2020R1C1C1007776, NRF-2020R1A2C1101616, NRF2017R1D1A1B04031319).

\section{Author Contribution}

Conceptualization: all authors. Data curation: Ji-Hoon Kim, Minhee Ku, Hyung Kwon Byeon. Formal analysis: Ji-Hoon Kim, Jaemoon Yang, Hyung Kwon Byeon. Funding acquisition: Jaemoon Yang, Hyung Kwon Byeon. Investigation: all authors. Methodology: all authors. Resources: all authors. Supervision: Jaemoon Yang, Hyung Kwon Byeon. Validation: Jaemoon Yang, Hyung Kwon Byeon. Visualization: Minhee Ku, Jaemoon Yang. Writing - original draft: Minhee $\mathrm{Ku}$, Hyung Kwon Byeon. Writing-review \& editing: Jaemoon Yang, Hyung Kwon Byeon.

\section{ORCIDs}

Hyung Kwon Byeon https://orcid.org/0000-0003-3709-2028

Ji-Hoon Kim https://orcid.org/0000-0002-0844-3047

Minhee $\mathrm{Ku} \quad$ https://orcid.org/0000-0002-1674-1474

Jaemoon Yang https://orcid.org/0000-0001-7365-0395

\section{REFERENCES}

1) Hanahan D, Weinberg RA. The hallmarks of cancer. Cell 2000; 100(1):57-70.

2) Hanahan D, Weinberg RA. Hallmarks of cancer: The next generation. Cell 2011;144(5):646-74.

3) Vander Heiden MG, Cantley LC, Thompson CB. Understanding the Warburg effect: The metabolic requirements of cell proliferation. Science 2009;324(5930):1029-33.

4) Warburg O, Wind F, Negelein E. The metabolism of tumors in the body. J Gen Physiol 1927;8(6):519-30.

5) Weinhouse S. Studies on the fate of isotopically labeled metabolites in the oxidative metabolism of tumors. Cancer Res 1951;11(8):58591.

6) Weinhouse S. Oxidative metabolism of neoplastic tissues. Adv Cancer Res 1955;3:269-325.

7) Fantin VR, St-Pierre J, Leder P. Attenuation of LDH-A expression uncovers a link between glycolysis, mitochondrial physiology, and tumor maintenance. Cancer Cell 2006;9(6):425-34.

8) Moreno-Sánchez R, Rodríguez-Enríquez S, Marín-Hernández A, Saavedra E. Energy metabolism in tumor cells. FEBS J 2007; 274(6):1393-418

9) DeBerardinis RJ, Lum JJ, Hatzivassiliou G, Thompson CB. The biology of cancer: Metabolic reprogramming fuels cell growth and proliferation. Cell Metab 2008;7(1):11-20.

10) Hay N. Reprogramming glucose metabolism in cancer: Can it be exploited for cancer therapy? Nat Rev Cancer 2016;16(10):635-49.

11) Sonveaux P, Végran F, Schroeder T, Wergin MC, Verrax J, Rabbani $\mathrm{ZN}$, et al. Targeting lactate-fueled respiration selectively kills hypoxic tumor cells in mice. J Clin Invest 2008;118(12):3930-42.

12) Stine ZE, Walton ZE, Altman BJ, Hsieh AL, Dang CV. MYC, metabolism, and cancer. Cancer Discov 2015;5(10):1024-39.

13) Pascual G, Avgustinova A, Mejetta S, Martín M, Castellanos A,
Attolini CS, et al. Targeting metastasis-initiating cells through the fatty acid receptor CD36. Nature 2017;541(7635):41-5.

14) Watt MJ, Clark AK, Selth LA, Haynes VR, Lister N, Rebello R, et al. Suppressing fatty acid uptake has therapeutic effects in preclinical models of prostate cancer. Sci Transl Med 2019;11(478):eaau5758.

15) Nieman KM, Kenny HA, Penicka CV, Ladanyi A, Buell-Gutbrod R, Zillhardt MR, et al. Adipocytes promote ovarian cancer metastasis and provide energy for rapid tumor growth. Nat Med 2011;17(11): 1498-503.

16) Balaban S, Shearer RF, Lee LS, van Geldermalsen M, Schreuder $\mathrm{M}$, Shtein HC, et al. Adipocyte lipolysis links obesity to breast cancer growth: Adipocyte-derived fatty acids drive breast cancer cell proliferation and migration. Cancer Metab 2017;5:1.

17) Currie E, Schulze A, Zechner R, Walther TC, Farese RV Jr. Cellular fatty acid metabolism and cancer. Cell Metab 2013;18(2):153-61.

18) Seo J, Kim KS, Park JW, Cho JY, Chang H, Fukuda J, et al. Metastasis-on-a-chip reveals adipocyte-derived lipids trigger cancer cell migration via HIF-1 $\alpha$ activation in cancer cells. Biomaterials 2021;269:120622

19) Mitsuishi $Y$, Taguchi K, Kawatani $Y$, Shibata T, Nukiwa T, Aburatani $\mathrm{H}$, et al. Motohashi $\mathrm{H}$. Nrf2 redirects glucose and glutamine into anabolic pathways in metabolic reprogramming. Cancer Cell 2012;22(1):66-79.

20) Berwick DC, Hers I, Heesom KJ, Moule SK, Tavare JM. The identification of ATP-citrate lyase as a protein kinase B (Akt) substrate in primary adipocytes. J Biol Chem 2002;277(37):33895900.

21) Liu Y. Fatty acid oxidation is a dominant bioenergetic pathway in prostate cancer. Prostate Cancer Prostatic Dis 2006;9(3):230-4.

22) Holder AM, Gonzalez-Angulo AM, Chen H, Akcakanat A, Do KA, Fraser Symmans W, et al. High stearoyl-CoA desaturase 1 expression is associated with shorter survival in breast cancer patients. Breast Cancer Res Treat 2013;137(1):319-27.

23) Huang J, Fan XX, He J, Pan H, Li RZ, Huang L, et al. SCD1 is associated with tumor promotion, late stage and poor survival in lung adenocarcinoma. Oncotarget 2016;7(26):39970-9.

24) Ackerman D, Tumanov S, Qiu B, Michalopoulou E, Spata M, Azzam A, et al. Triglycerides promote lipid homeostasis during hypoxic stress by balancing fatty acid saturation. Cell Rep 2018; 24(10):2596-605.e5.

25) Kamphorst JJ, Cross JR, Fan J, de Stanchina E, Mathew R, White EP, et al. Hypoxic and Ras-transformed cells support growth by scavenging unsaturated fatty acids from lysophospholipids. Proc Natl Acad Sci U S A 2013;110(22):8882-7.

26) Rysman E, Brusselmans K, Scheys K, Timmermans L, Derua R, Munck S, et al. De novo lipogenesis protects cancer cells from free radicals and chemotherapeutics by promoting membrane lipid saturation. Cancer Res 2010;70(20):8117-26.

27) Zalba S, Ten Hagen TLM. Cell membrane modulation as adjuvant in cancer therapy. Cancer Treat Rev 2017;52:48-57.

28) Lee CK, Jeong SH, Jang C, Bae H, Kim YH, Park I, et al. Tumor metastasis to lymph nodes requires YAP-dependent metabolic adaptation. Science 2019;363(6427):644-9.

29) Jeon SM, Chandel NS, Hay N. AMPK regulates NADPH homeostasis to promote tumour cell survival during energy stress. Nature 2012; 485(7400):661-5.

30) Zhang M, Di Martino JS, Bowman RL, Campbell NR, Baksh SC, Simon-Vermot T, et al. Adipocyte-derived lipids mediate melanoma progression via FATP proteins. Cancer Discov 2018;8(8):1006-25.

31) Carvalho MA, Zecchin KG, Seguin F, Bastos DC, Agostini M, Rangel ALCA, et al. Fatty acid synthase inhibition with orlistat promotes apoptosis and reduces cell growth and lymph node metastasis in a mouse melanoma model. Int J Cancer 2008;123(11): 2557-65. 
32) Loftus TM, Jaworsky DE, Frehywot GL, Townsend CA, Ronnett $\mathrm{GV}$, Lane MD, et al. Reduced food intake and body weight in mice treated with fatty acid synthase inhibitors. Science 2000;288(5475): 2379-81.

33) Zadra G, Ribeiro CF, Chetta P, Ho Y, Cacciatore S, Gao X, et al. Inhibition of de novo lipogenesis targets androgen receptor signaling in castration-resistant prostate cancer. Proc Natl Acad Sci U S A 2019;116(2):631-40.

34) Wang X, Tian W. Green tea epigallocatechin gallate: A natural inhibitor of fatty-acid synthase. Biochem Biophys Res Commun 2001;288(5):1200-6.

35) Lupu R, Menendez JA. Pharmacological inhibitors of fatty acid synthase (FASN)--catalyzed endogenous fatty acid biogenesis: A new family of anti-cancer agents? Curr Pharm Biotechnol 2006; 7(6):483-93.

36) Knobloch M, Braun SM, Zurkirchen L, von Schoultz C, Zamboni $\mathrm{N}$, Araúzo-Bravo MJ, et al. Metabolic control of adult neural stem cell activity by Fasn-dependent lipogenesis. Nature 2013;493(7431): 226-30.

37) Jiang L, Xiao L, Sugiura H, Huang X, Ali A, Kuro-o M, et al. Metabolic reprogramming during TGF $\beta 1$-induced epithelial-tomesenchymal transition. Oncogene 2015;34(30):3908-16.

38) Thupari JN, Landree LE, Ronnett GV, Kuhajda FP. C75 increases peripheral energy utilization and fatty acid oxidation in diet-induced obesity. Proc Natl Acad Sci U S A 2002;99(14):9498-502.

39) Zaytseva YY, Rychahou PG, Le AT, Scott TL, Flight RM, Kim JT, et al. Preclinical evaluation of novel fatty acid synthase inhibitors in primary colorectal cancer cells and a patient-derived xenograft model of colorectal cancer. Oncotarget 2018;9(37):24787-800.

40) Menendez JA, Lupu R. Fatty acid synthase (FASN) as a therapeutic target in breast cancer. Expert Opin Ther Targets 2017;21(11):100116.

41) Migita T, Narita T, Nomura K, Miyagi E, Inazuka F, Matsuura M, et al. ATP citrate lyase: Activation and therapeutic implications in non-small cell lung cancer. Cancer Res 2008;68(20):8547-54.

42) Hatzivassiliou G, Zhao F, Bauer DE, Andreadis C, Shaw AN, Dhanak D, et al. ATP citrate lyase inhibition can suppress tumor cell growth. Cancer Cell 2005;8(4):311-21.

43) Beckers A, Organe S, Timmermans L, Scheys K, Peeters A, Brusselmans K, et al. Chemical inhibition of acetyl-CoA carboxylase induces growth arrest and cytotoxicity selectively in cancer cells. Cancer Res 2007;67(17):8180-7.

44) Wang C, Xu C, Sun M, Luo D, Liao DF, Cao D. Acetyl-CoA carboxylase-alpha inhibitor TOFA induces human cancer cell apoptosis. Biochem Biophys Res Commun 2009;385(3):302-6.

45) Luo J, Hong Y, Lu Y, Qiu S, Chaganty BKR, Zhang L, et al. AcetylCoA carboxylase rewires cancer metabolism to allow cancer cells to survive inhibition of the Warburg effect by cetuximab. Cancer Lett 2017;384:39-49.

46) Yang J, Guo Y, Seo W, Zhang R, Lu C, Wang Y, et al. Targeting cellular metabolism to reduce head and neck cancer growth. Sci Rep 2019;9(1):4995.

47) Li X, Chen YT, Hu P, Huang WC. Fatostatin displays high antitumor activity in prostate cancer by blocking SREBP-regulated metabolic pathways and androgen receptor signaling. Mol Cancer Ther 2014; 13(4):855-66.

48) Chen M, Zhang J, Sampieri K, Clohessy JG, Mendez L, GonzalezBillalabeitia E, et al. An aberrant SREBP-dependent lipogenic program promotes metastatic prostate cancer. Nat Genet 2018; 50(2):206-18

49) Tang JJ, Li JG, Qi W, Qiu WW, Li PS, Li BL, et al. Inhibition of SREBP by a small molecule, betulin, improves hyperlipidemia and insulin resistance and reduces atherosclerotic plaques. Cell Metab 2011;13(1):44-56
50) Chen W, Chen G, Head DL, Mangelsdorf DJ, Russell DW. Enzymatic reduction of oxysterols impairs LXR signaling in cultured cells and the livers of mice. Cell Metab 2007;5(1):73-9.

51) Flaveny CA, Griffett K, El-Gendy Bel-D, Kazantzis M, Sengupta M, Amelio AL, et al. Broad anti-tumor activity of a small molecule that selectively targets the warburg effect and lipogenesis. Cancer Cell 2015;28(1):42-56.

52) Marien E, Meister M, Muley T, Gomez Del Pulgar T, Derua R, Spraggins JM, et al. Phospholipid profiling identifies acyl chain elongation as a ubiquitous trait and potential target for the treatment of lung squamous cell carcinoma. Oncotarget 2016;7(11):12582-97.

53) Peck B, Schug ZT, Zhang Q, Dankworth B, Jones DT, Smethurst E, et al. Inhibition of fatty acid desaturation is detrimental to cancer cell survival in metabolically compromised environments. Cancer Metab 2016;4:6

54) Mason P, Liang B, Li L, Fremgen T, Murphy E, Quinn A, et al. SCD1 inhibition causes cancer cell death by depleting monounsaturated fatty acids. PLoS One 2012;7(3):e33823.

55) Potze L, di Franco S, Kessler JH, Stassi G, Medema JP. Betulinic acid kills colon cancer stem cells. Curr Stem Cell Res Ther 2016; 11(5):427-33.

56) Ma MKF, Lau EYT, Leung DHW, Lo J, Ho NPY, Cheng LKW, et al. Stearoyl-CoA desaturase regulates sorafenib resistance via modulation of ER stress-induced differentiation. J Hepatol 2017; 67(5):979-90.

57) Pisanu ME, Noto A, De Vitis C, Morrone S, Scognamiglio G, Botti $\mathrm{G}$, et al. Blockade of stearoyl-CoA-desaturase 1 activity reverts resistance to cisplatin in lung cancer stem cells. Cancer Lett 2017; 406:93-104

58) Vriens K, Christen S, Parik S, Broekaert D, Yoshinaga K, Talebi A, et al. Evidence for an alternative fatty acid desaturation pathway increasing cancer plasticity. Nature 2019;566(7744):403-6.

59) Luo J, Hong Y, Tao X, Wei X, Zhang L, Li Q. An indispensable role of CPT-1a to survive cancer cells during energy stress through rewiring cancer metabolism. Tumour Biol 2016;37:15795-804.

60) Liu PP, Liu J, Jiang WQ, Carew JS, Ogasawara MA, Pelicano H, et al. Elimination of chronic lymphocytic leukemia cells in stromal microenvironment by targeting CPT with an antiangina drug perhexiline. Oncogene 2016;35(43):5663-73.

61) Kantor PF, Lucien A, Kozak R, Lopaschuk GD. The antianginal drug trimetazidine shifts cardiac energy metabolism from fatty acid oxidation to glucose oxidation by inhibiting mitochondrial long-chain 3-ketoacyl coenzyme A thiolase. Circ Res 2000; 86(5):580-8.

62) Nash DT, Nash SD. Ranolazine for chronic stable angina. Lancet 2008;372(9646):1335-41.

63) Pollak MN. Investigating metformin for cancer prevention and treatment: The end of the beginning. Cancer Discov 2012;2(9):77890.

64) Sadowski MC, Pouwer RH, Gunter JH, Lubik AA, Quinn RJ, Nelson CC. The fatty acid synthase inhibitor triclosan: Repurposing an anti-microbial agent for targeting prostate cancer. Oncotarget 2014;5(19):9362-81.

65) Fritz V, Benfodda Z, Rodier G, Henriquet C, Iborra F, Avancès C, et al. Abrogation of de novo lipogenesis by stearoyl-CoA desaturase 1 inhibition interferes with oncogenic signaling and blocks prostate cancer progression in mice. Mol Cancer Ther 2010;9(6):1740-54.

66) Carracedo A, Cantley LC, Pandolfi PP. Cancer metabolism: Fatty acid oxidation in the limelight. Nat Rev Cancer 2013;13(4):227-32.

67) Shackelford DB, Abt E, Gerken L, Vasquez DS, Seki A, Leblanc $\mathrm{M}$, et al. LKB1 inactivation dictates therapeutic response of nonsmall cell lung cancer to the metabolism drug phenformin. Cancer Cell 2013;23(2):143-58. 


\section{정답 및 해설}

1. 답 (2)

해 설 대개는 선천성으로 발생하며, 신생아의 4 16\%까지 나타나고 남아에서 호발한다.

참고 문헌: Kim JE, Keum BR, Li SW, Park SM, Kwon B, Kim H, et al. The effect of frenotomy on the tongue length, motion, and speech according to age. Korean J Otorhinolaryngol-Head Neck Surg 2021;64(2):98-102.

대한이비인후과학회, 이비인후과학:두경부. 개정2판. 파주: 군자출판사;2018, p.310-1.

2. 답 (5)

해 설 (1) 제4새열낭종이 의심된다.

(2) 선천성 경부종괴의 가장 흔한원인인 이 질환은 주로 흉쇄유돌근의 하방 $1 / 3$ 전방에 위치한다.

(3) 감염 등으로 통증과 크기가 커지는 증상이 발생할 수 있다.

(4) 일측성으로 생기는 경우가 많으며 위의 새열낭종(4형)은 주로 경부 좌측에 발생한다.

참고 문헌: Han JH, Park IS. A case of fourth branchial cleft cyst occurred on the right side. Korean J Otorhinolaryngol-Head Neck Surg 2021;64(1):30-3.

대한이비인후과학회, 이비인후과학:두경부. 개정2판. 파주: 군자출판사;2018, p.577-82. 